\title{
The Spatial Analysis to Choose a Location to be Designated as a Landfill Site
}

\author{
Zaflis Zaim ${ }^{1 *}$, Febby Asteriani ${ }^{2}$ \\ ${ }^{1.2}$ Urban \& Regional Planning Department, Universitas Islam Riau, Indonesia \\ ${ }^{*}$ Doctoral Student, Faculty of Engineering, Universitas Diponegoro Semarang Indonesia
}

\begin{abstract}
Pekanbaru city has a landfill site (TPA). The local government estimated that it could only accommodate disposal for the next 2 years and a half. The aims of this research are: to identify a location suitable to be designated as a landfill site and considering to the land use change. The methods it employed were the overlay technique in Geographic Information System and Technique for Order Preference by Similarity to Ideal Solution (TOPSIS) as non-spatial analysis. Research findings found 4 feasible locations using GIS, i.e: Palas Sub-district and Rumbai Bukit Subdistrict in Rumbai; Tebing Okura Sub-district in Rumbai Pesisir; Sail Subdistrict in Tenayan Raya; and Labuh Baru Sub-district in Payung Sekaki District. From the TOPSIS, a number of locations with a specific rank were found such as: Rumbai, Rumbai Pesisir, Tenayan Raya \& Tampan District. This research have one recommendation namely that Rumbai is the most suitable district to be designated as a landfill site.
\end{abstract}

\section{Introduction}

The TPA has been established since 1987 situated in Muara Fajar. It produces $1.816 \mathrm{~m}^{3}$ of waste per day from 12 districts and has over capacity. There are 18.062 residents who working in agriculture sector ${ }^{[3]}$, and product i.e: paddy, maizena flour, cassava, crops, chili and fruits. According to Borges, Fragoso, et al: land use is the key for human activity that drives socio-economic development in rural regions ${ }^{[4]}$. Therefore, the agriculture area in the urban fringe need protection to guarantee a sustainable agriculture land management. That is to determine the best position to establish lasting monuments and other valuable place [5]. This study fills this gap and was conducted with the objective to determine a location suitable to be designated as a landfill site. It will make an alternative method in landfill site selection \& geomorphic study in planning ${ }^{[1]}$.

\section{Method \& Analysis}

The spatial analysis overlaid maps to describe some phenomena using Arcview. This research has define 9 criteria which were devided into 2 categories (see table 1 and 2).

\footnotetext{
* Corresponding author: zaflis@eng.uir.ac.id
} 
Table 1: The Regional Feasibility Category

\begin{tabular}{|c|c|c|c|c|}
\hline Code & Parameter & Weight & Criteria & Score \\
\hline K1 & Slope & 5 & $\begin{array}{l}>15 \% \\
5-15 \% \\
0-5 \%\end{array}$ & $\begin{array}{l}1 \\
2 \\
3\end{array}$ \\
\hline K2 & Geological Condition & 4 & $\begin{array}{l}\text { Not situated within the active fault zone } \\
\text { Situated within the active fault zone }\end{array}$ & $\begin{array}{l}3 \\
1\end{array}$ \\
\hline K3 & Distance to the Water Body & 3 & $\begin{array}{l}>100 \mathrm{~m} \\
<100 \mathrm{~m}\end{array}$ & $\begin{array}{l}3 \\
1\end{array}$ \\
\hline K4 & $\begin{array}{l}\text { Distance to the Residential } \\
\text { Area }\end{array}$ & 5 & $\begin{array}{l}>1500 \mathrm{~m} \\
<1500 \mathrm{~m}\end{array}$ & $\begin{array}{l}3 \\
1\end{array}$ \\
\hline K5 & $\begin{array}{l}\text { Distance to the Agricultural } \\
\text { Area }\end{array}$ & 3 & $\begin{array}{l}>150 \mathrm{~m} \text { from the agricultural area } \\
<150 \mathrm{~m} \text { from the agricultural area }\end{array}$ & $\begin{array}{l}3 \\
1\end{array}$ \\
\hline K6 & $\begin{array}{l}\text { Distance to the Protected } \\
\text { Area }\end{array}$ & 2 & $\begin{array}{l}\text { Situated outside the protected area } \\
\text { Situated within the protected area }\end{array}$ & $\begin{array}{l}3 \\
1\end{array}$ \\
\hline K7 & $\begin{array}{l}\text { Distance to the Outskirts of } \\
\text { the City }\end{array}$ & 5 & $\begin{array}{l}>1000 \mathrm{~m} \\
<1000 \mathrm{~m}\end{array}$ & $\begin{array}{l}3 \\
1\end{array}$ \\
\hline
\end{tabular}

Table 2: The Filter Feasibility Category

\begin{tabular}{|c|c|c|c|c|}
\hline Code & Parameter & Weight & Criteria & Score \\
\hline K8 & $\begin{array}{l}\text { Rainfall } \\
\text { intensity }\end{array}$ & 2 & $\begin{array}{l}>1000 \mathrm{~mm} / \text { year } \\
500-1000 \mathrm{~mm} / \text { year } \\
<500 \mathrm{~mm} / \text { year }\end{array}$ & $\begin{array}{l}1 \\
2 \\
3\end{array}$ \\
\hline K9 & $\begin{array}{l}\text { Flood-Prone } \\
\text { Area }\end{array}$ & 2 & $\begin{array}{l}\text { There are no flood hazards. } \\
\text { The probability of flood is more than } 25 \text { years. } \\
\text { The probability of flood is less than } 25 \text { years. }\end{array}$ & $\begin{array}{l}3 \\
2 \\
1\end{array}$ \\
\hline
\end{tabular}

Source: Results of the Analysis \& SNI (Indonesia National Standard) number: 03-3241-1994.

\section{Research Findings}

\subsection{Spatial Analysis of the Selection of the Landfill Location}

\subsubsection{The Regional Feasibility Criteria}

\subsubsection{Slope}

The ideal slope for a landfill ranges from 0 to $20 \%$. There are two colors, the pink zone refers to the area which is not suitable to be designated as a landfill which cover the following districts: some areas in Rumbai, Rumbai Pesisir \& Tenayan Raya.

\subsubsection{Protected Area}

In the map, there are two zones, namely the green zone, which is located within the protected areas, and the yellow zone, which is located outside the protected area.

\subsubsection{The Overlay of the Regional Feasibility and Filter Feasibility Map}

Based on the overlay result, Rumbai District especially in Palas and Rumbai Bukit Subdistrict, is considered a zone suitable to be designated as a landfill site. Palas \& Rumbai Bukit Sub-district have a slope ranging from 2 to $15 \%$ which falls into the slightly sloping category. The potential location 3 (Tebing Okura) has a slope ranging from 2 to $8 \%$. 


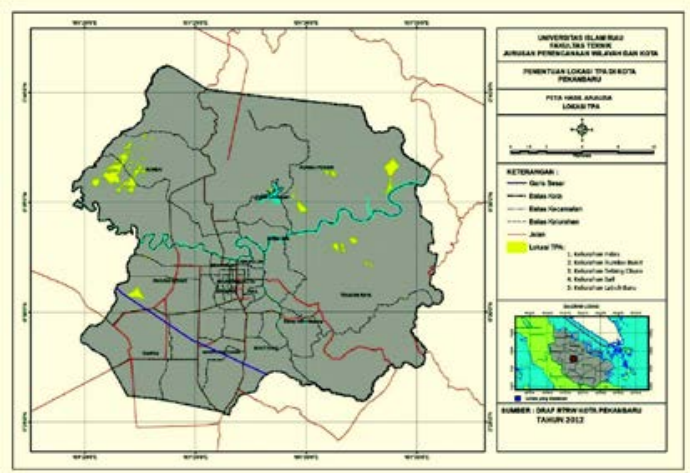

Fig 1. The Map Generated by the Analysis Illustrating as Potential Locations.

Table 3. Scores for the Regional Feasibility and Filter Feasibility Criteria

\begin{tabular}{|c|l|r|r|r|r|r|}
\hline \multirow{2}{*}{ No } & \multirow{2}{*}{ Score Classification } & \multicolumn{5}{|c|}{ Sub-district } \\
\cline { 3 - 7 } & Ralas & R.Bukit & T.Okura & Sail & L.Baru \\
\hline \multicolumn{2}{|c|}{ Regional Feasibility } & & & & & \\
\hline 1 & Slope & 15 & 15 & 15 & 15 & 15 \\
\hline 2 & Geological Condition & 12 & 12 & 12 & 12 & 4 \\
\hline 3 & Distance to the Water Body & 9 & 9 & 9 & 9 & 9 \\
\hline 4 & Distance to the Residential & 15 & 15 & 15 & 15 & 5 \\
\hline 5 & Agricultural Area & 9 & 9 & 9 & 9 & 9 \\
\hline 6 & Protected Area & 4 & 4 & 4 & 4 & 4 \\
\hline 7 & Distance to the Outskirts of the city & 15 & 15 & 15 & 15 & 15 \\
\hline Filter Feasibility & & & & & \\
\hline 8 & Rainfall Intensity & 6 & 6 & 6 & 6 & 6 \\
\hline 9 & Flood-Prone Area & 6 & 6 & 6 & 6 & 6 \\
\hline \multicolumn{2}{|c|}{ Total } & 91 & 91 & 91 & 91 & 73 \\
\hline
\end{tabular}

Total $=$ Score $*$ Criterion Weight

\subsection{The Non-Spatial Analysis for Landfill Site Selection}

To support the results of spatial analysis, TOPSIS method that classifies districts on the ranking basis was performed as alternative landfill locations, also to strengthen the basis for decision making as well. There are weights and criteria set to determine the selected alternative as alternative landfill locations. Each category has a criterion weight between 1 and 5 namely the categories very bad (1), bad (2), fairly good (3), good (4), excellent (5).

\subsubsection{Developing the Decision Matrix}

The matrix column states that the attributes are comprised of the existing criteria, whereas the matrix row states that the alternative is the assessment data on the zones suitable to be used as a landfill to be compared.

$$
\mathrm{D}=\left[\begin{array}{llll}
x_{11} & x_{12} & \ldots & x_{1 \mathrm{n}} \\
x_{21} & x_{22} & \ldots & x_{2 \mathrm{n}} \\
x_{\mathrm{m} 1} & x_{\mathrm{m} 2} & \ldots & x_{\mathrm{mn}}
\end{array}\right]
$$

$\mathrm{D}=$ Decision matrix

$$
\mathrm{n}=\text { total criteria }
$$

$\mathrm{m}=$ Total number of alternatives.

Symbols $x_{11} \ldots x_{34}=$ indicate the performance of the alternatives. 


\subsubsection{Calculating the total score for $x$ (the alternative score for each criterion)}

$$
\begin{aligned}
& \text { Total } X_{1}=\sqrt{ } A_{1}{ }^{2}+\ldots A_{12}{ }^{2}
\end{aligned}
$$

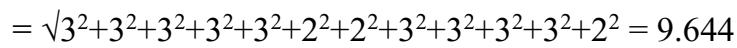

A1=Bukit Raya; A2=Lima Puluh; A3=Marpoyan Damai; A4=Payung Sekaki; A5=Pekanbaru Kota; A6=Rumbai Pesisir; A7=Rumbai; A8=Sail; A9=Senapelan; A10=Sukajadi; A11=Tampan; A12 =Tenayan Raya.

\subsubsection{Developing the normalized decision matrix}

Once the decision matrix has been developed, the next step was to develop the normalized decision matrix $\mathrm{R}$, in which the elements are determined using:

$$
r_{\mathrm{ij}}=\frac{X_{\mathrm{ij}}}{\sqrt{\sum_{i=1}^{m} X_{i j}^{2}}}
$$

where $i=1,2,3, \ldots . m$; and $j=1,2,3, \ldots, n$

An example of the normalized matrix calculation (matrix $\mathrm{R}$ ) for $\mathrm{K}_{1}$ in Bukit Raya:

$$
R_{1,1}=\left(\frac{A_{1.1}}{\sum X_{1}}\right)=\left(\frac{3}{9.644}\right)=0.311
$$

\subsubsection{Developing the weighted normalized decision matrix}

With the weight $w_{\mathrm{j}}=\left(w_{1}, w_{2}, \ldots w_{\mathrm{n}}\right)$, where $\mathrm{w}_{\mathrm{j}}$ is the weight of the $\mathrm{j}^{\text {th }}$ criterion and $\sum_{\mathrm{j}=1}^{\mathrm{n}} w_{j}=1$, thus the weight normalisation of the matrix $\mathrm{V}$ is:

$$
V_{\mathrm{ij}}=W_{\mathrm{ij}} * r_{\mathrm{ij}}
$$

$V_{1,1}=$ Criterion Weight $* R_{1,1}$

$=5 * 0.311=1.555$ (this calculation for Criterion- 1 in Bukit Raya District)

\subsubsection{Determining the positive and negative ideal solution matrices}

The positive ideal solution is denoted by the symbol $\mathrm{A}+$, while the negative ideal solution is denoted by the symbol A-.

$$
\begin{gathered}
\begin{aligned}
A^{+} & =\left\{\left(\max v_{\mathrm{ij}} \mid \mathrm{j} € \mathrm{~J}\right),\left(\min v_{\mathrm{ij}} \mid \mathrm{j} € \mathrm{~J}\right), \mathrm{i}=1,2,3, \ldots, \mathrm{m}\right\} \\
& =v_{1^{-}}, v_{2}^{-}, v_{3}^{-}, \ldots v_{\mathrm{n}}^{-}
\end{aligned} \\
A^{-}=\left\{\left(\min v_{\mathrm{ij}} \mid \mathrm{j} € \mathrm{~J}\right),\left(\max v_{\mathrm{ij}} \mid \mathrm{j} € \mathrm{~J}\right), \mathrm{i}=1,2,3, \ldots, \mathrm{m}\right\}
\end{gathered}
$$

$J=\left\{j=1,2, . ., n\right.$ and $J$ is the benefit criterion. $J^{\prime}=\{j=1,2 . ., n\} \& J^{\prime}$ is the cost criterion.

\subsubsection{Calculating Separation}

$D^{+}$is the alternative distance (in the Euclidean perspective) from the positive ideal solutions

$$
D_{l}^{+}=\sqrt{\sum_{\mathrm{i}=1}^{\mathrm{n}}\left(v \mathrm{j}^{+}-v \mathrm{ij}\right)^{2}} \text {, with } \mathrm{j}=1,2,3 \ldots, \mathrm{n}
$$


$D^{-}$is the alternative distance from the negative ideal solution. It is described as:

$$
D_{l^{-}}=\sqrt{\sum_{\mathrm{i}=1}^{\mathrm{n}}\left(v \mathrm{j}^{-}-v \mathrm{ij}\right)^{2}} \text {, with } \mathrm{j}=1,2,3, \ldots, \mathrm{n}
$$

$v_{\mathrm{ij}}=$ element of the weighted normalized decision matrix $\mathrm{V}$

$v_{1}{ }^{+}=$element of the positive ideal solution

$v_{1}{ }^{-}=$element of the negative ideal solution

An example of the distance calculation for positive $\left(\mathrm{D}^{+}\right)$and negative $\left(\mathrm{D}^{-}\right)$.

$$
\begin{gathered}
D^{+}=\sqrt{\sum_{\mathrm{i}=1}^{\mathrm{n}}\left(v \mathrm{j}^{+}-v \mathrm{ij}\right)^{2}} \\
\left.=\sqrt{\left(A 1^{+}\right.}-V_{1.1}\right)^{2}+\left(A 2^{+}-V_{1.2)^{2}}+\ldots A 9^{+}-V_{1.9}\right)^{2}
\end{gathered}
$$

$D^{-}$the alternative distance from the negative ideal solution, which is defined:

$$
\begin{gathered}
D^{-}=\sqrt{\sum_{\mathrm{i}=1}^{\mathrm{n}}\left(v \mathrm{j}^{-}-v \mathrm{ij}\right)^{2}} \\
\left.\left.=\sqrt{\left(A_{1}^{-}\right.}-V_{1.1}\right)^{2}+\left(A_{2}^{-}-V_{1.2}\right)^{2}+\ldots A 9^{-}-V_{1.9}\right)^{2}
\end{gathered}
$$

3.2.7. Calculating the relative proximity to the ideal positive solution

$$
V_{1}^{+}=\left(\frac{\mathrm{Di}^{-}}{\mathrm{Di}^{+}+\mathrm{Di}^{-}}\right), 0 \leq D_{\mathrm{i}^{+}} \leq 1
$$

$\mathrm{V}_{\mathrm{i}}^{+}$is the relative proximity from the $\mathrm{I}^{\text {th }}$ alternative to the positive ideal solution.

$$
V_{1}=\frac{2.153}{2.153+1.570}=0,578
$$

Table 4. Ranking of the Alternatives

\begin{tabular}{|l|c|l|}
\hline Code & \multicolumn{1}{|c|}{ Score } & \multicolumn{1}{|c|}{ Alternative } \\
\hline V7 & 0.780 & Rumbai District \\
\hline V6 & 0.691 & Rumbai Pesisir District \\
\hline V12 & 0.657 & Tenayan Raya District \\
\hline V11 & 0.578 & Tampan District \\
\hline V1 & 0.578 & Bukit Raya District \\
\hline V4 & 0.482 & Payung Sekaki District \\
\hline V2 & 0.475 & Lima Puluh District \\
\hline V3 & 0.469 & Marpoyan Damai District \\
\hline V8 & 0.412 & Senapelan District \\
\hline V9 & 0.391 & Sail District \\
\hline V5 & 0.378 & Pekanbaru Kota District \\
\hline V10 & 0.365 & Sukajadi District \\
\hline
\end{tabular}

\subsection{Recapitulation of the Potential Locations}

Based on the recapitulation results of the spatial analysis (GIS) and TOPSIS, there are 3 districts with the same score, namely Rumbai, Rumbai Pesisir and Tenayan Raya. 
Table 5. The Recapitulation of the Potential Locations for Landfill Site according to Districts

\begin{tabular}{|c|l|c|l|c|}
\hline Rank & Spatial Analysis (SIG) & Score & Non-Spatial Analysis (TOPSIS) & Score \\
\hline 1 & Rumbai District & 91 & Rumbai District & 0.780 \\
\hline 2 & Rumbai Pesisir District & 91 & Rumbai Pesisir District & 0.691 \\
\hline 3 & Tenayan Raya District & 91 & Tenayan Raya District & 0.657 \\
\hline 4 & Payung Sekaki District & 73 & Tampan District & 0.578 \\
\hline
\end{tabular}

\subsection{The Indicator of Land Use Change for Landfill-Related Decision Making}

The considerations can be supported through physical observation of the urban land especially in terms of the trend of land use changes. The process of land use changes can be explained based on the map. After enactment of the regional division policy in 1987, there are 3 types of land use shifting patterns identified, namely concentrated in CBD; the linear and the leap frog pattern ${ }^{[2] . ~ F r o m ~ t h e ~ m a p ~ b e l o w, ~ i t ~ i s ~ s h o w n ~ t h a t ~ l a n d ~ u s e ~ c h a n g e s ~ a r e ~ n o t ~}$ so massive and fast in the northern part of the City. Land use changes are still focused on the southern part of the city or in the south of Siak River. This can be caused by the distribution of primary functions of the City which are widely spread in South of the city thus affecting the acceleration of the physical residential area. The northern areas, namely Rumbai Bukit \& Palas Sub-districts can be considered as the location for new landfill site.

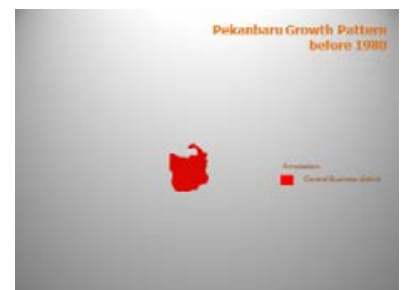

(1980)

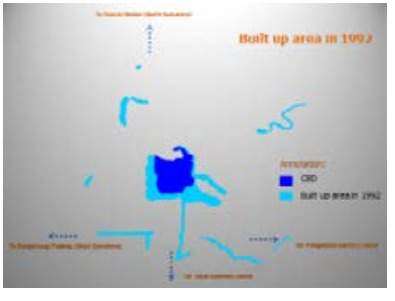

(1992)

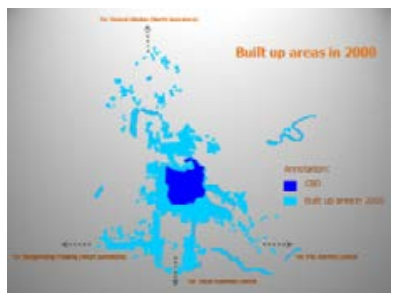

(2000)

Fig 2. The Process of Land Use Changes in Pekanbaru

\section{Conclusions}

Nowadays, GIS technology applied to find the best solution such as land use issues. GISbased mapping methods can suggest a more specific location that GIS software \& using digital maps can collect data, select and process spatial data through an information analysis. TOPSIS only ranks the values of criteria for each alternative, where all the alternatives are comprised of districts. As one of advanced engineering, GIS are recommended to solve a problems in determination of the ideal location of landfill site. We suggest to make cooperation between local government to provide a common landfill. This effort can reduce the problems of landfill site in fast growing cities.

\section{References}

1. Adeli, Z \& Ali Mohammad K., Appl of geomorphology in urban planning: Case study in landfill site selection, Procedia Social \& Behavioral Sciences 19, p.662-667 (2011).

2. Malik, Hapriadi., Physical Growth of Pekanbaru City after Expansion; Thesis at Graduate School Gadjah Mada University Yogyakarta, unpublish, p.96 (2002).

3. Badan Pusat Statistik., Pekanbaru in Figures, BPS Pekanbaru (2012).

4. Borges, P.J., Fragoso, R., Garcia-Gonzalo, J., Borges, J.G., et al., Assessing impacts of Common Agricultural Policy changes on regional land use patterns with a decision support system; An Appl in Southern Portugal, Forest Policy \& Economics 12 (2010).

5. Motamed. A, Moghimi., Application of Geomorphology in Urban Planning, (1998). 